\title{
SUNTIK MATI (EUTHANASIA) DITINJAU DARI ASPEK HUKUM PIDANA DAN HAK ASASI MANUSIA DI INDONESIA
}

\author{
Tjandra Sridjaja Pradjonggo \\ Program Studi Ilmu Hukum Fakultas Hukum Universitas Wisnuwardhana Malang \\ Jl. Danau Sentani No.99 Malang \\ email:Tjandra.Sridjaja@yahoo.com
}

\begin{abstract}
Euthanasia problem has existed since the health system faces an incurable disease, while the patient is dying and torture. In such situations, it is not uncommon patient begged to be released from this suffering and did not want an extended life again or in other circumstances in patients who are not aware, families of patients who did not have the heart to see patients suffering deathbed ask the doctor or nurse not to continue treatment or if necessary, provide drugs to hasten death. From this emerged the term euthanasia, which took off a person's life to be free from suffering or dying well. From the study of this thesis can be concluded that the lethal injection, or more commonly called euthanasia if viewed from the aspect of criminal law and human rights in Indonesia are still having a debate that has not found the end, because of the provision of human rights by the opposition national laws, especially the Criminal Code in force in Indonesia, but basically that the act of euthanasia is still Brazilians is prohibited in the criminal justice system and health laws that exist in Indonesia, whatever and however excuse used and anyone who filed either personally want themselves or family everything is still forbidden to do anything syringe the dead, even the health workers are still prohibited from lethal injection for any reason.
\end{abstract}

Keyword: euthanasia, criminal law, human rights

\begin{abstract}
Abstrak: Permasalahan euthanasia sudah ada sejak kalangan kesehatan menghadapi penyakit yang tak tersembuhkan, sementara pasien sudah dalam keadaan sekarat dan menyiksa. Dalam situasi demikian, tidak jarang pasien memohon agar dibebaskan dari penderitaan ini dan tidak ingin diperpanjang hidupnya lagi atau di lain keadaan pada pasien yang sudah tidak sadar, keluarga pasien yang tidak tega melihat pasien yang penuh penderitaan menjelang ajalnya meminta kepada dokter atau perawat untuk tidak meneruskan pengobatan atau bila perlu memberikan obat yang mempercepat kematian. Dari sinilah istilah euthanasia muncul, yaitu melepas kehidupan seseorang agar terbebas dari penderitaan atau mati secara baik. Dari kajian penulisan tesis ini dapat di simpulkan bahwa suntik mati atau lebih sering disebut eutanasia jika ditinjau dari aspek hukum pidana dan hak asasi manusia di indonesia masih mengalami perdebatan yang belum menemukan ujung, karena antara pemberian hak asasi manusia dengan pertentangan hukum nasional khususnya KUHP yang diberlakukan di Indonesia, tetapi pada dasarnya bahwa perbuatan eutanasia masih meupakan perbuatan yang dilarang dalam sistem hukum pidana maupun hukum kesehatan yang ada di Indonesia, apapun dan bagaimanapun alasan yang digunakan dan siapapun yang mengajukan baik pribadi yang menginginkan sendiri maupun keluarga semuanya masih dilarang untuk melakukan perbuatan suntik mati tersebut, bahkan tenaga kesehatan juga masih dilarang untuk melakukan suntik mati tersebut dengan alasan apapun.
\end{abstract}

Kata Kunci: suntik mati, hukum pidana, hak asasi manusia

Istilah euthanasia berasal dari bahasa Yunani, yaitu $e u$ dan thanatos. Kata $e u$ berarti baik, tanpa penderitaan dan thanatos berarti mati. Istilah euthanasia berasal dari bahasa Yunani, yaitu $e u$ dan thanatos. Kata $e u$ berarti baik, tanpa penderitaan dan thanatos berarti mati, maka dari itu dalam mengadakan euthanasia arti sebenarnya bukan untuk menyebabkan kematian, akan tetapi untuk mengurangi atau meringankan penderitaan orang yang sedang menghadapi kematiannya. Dalam arti 
yang demikian itu euthanasia tidaklah bertentangan dengan panggilan manusia untuk mempertahankan dan memperkembangkan hidupnya, sehingga tidak menjadi persoalan dari segi kesusilaan. Artinya, dari segi kesusilaan dapat dipertanggungjawabkan bila orang yang bersangkutan menghendakinya.

Dalam kehidupan setiap makhluk hidup pasti mengalami siklus kehidupan yang diawali dengan proses-proses kehidupan yang dimulai dari prses pembuahan, kelahiran, kehidupan di dunia, dan diakhiri dengan kematian. Dalam proses tersebut, kematian memiliki misteri besar yang belum ditemukan oleh ilmu pengetahuan. Secara umum, kematian adalah suatu hal yang ditakuti oleh masyarakat luas. Namun, tidak demikian dalam kalangan medis dan kesehatan. Dalam konteks kesehatan modern, kematian tidaklah selalu menjadi sesuatu yang datang secara tiba-tiba. Kematian dapat dilegalisir menjadi sesuatu yang definit dan dapat ditentukan tanggal kejadiannya. Tindakan membunuh bisa dilakukan secara legal dan dapat diprediksi waktu dan tempatnya itulah yang selama ini disebut dengan euthanasia, pembunuhan yang sampai saat ini masih menjadi kontroversi dan belum bisa diatasi dengan baik atau dicapainya kesepakatan yang diterima oleh berbagai pihak. Di satu pihak, tindakan euthanasia pada berbagai kasus dan keadaan memang diperlukan. Sementara di lain pihak, tindakan ini tidak diterima karena bertentangan dengan hukum, moral, dan agama.

Dilema muncul dan menempatkan dokter atau perawat pada posisi yang serba sulit. Tenaga medis merupakan suatu profesi yang mempunyai kode etik tersendiri sehingga mereka dituntut untuk bertindak secara professional. Tenaga medis merasa mempunyai tanggung jawab untuk membantu menyembuhkan penyakit pasien, sedangkan di pihak lain, pengetahuan dan kesadaran masyarakat terhadap hak-hak individu juga sudah sangat berubah. Dengan demikian, konsep kematian dalam dunia kedokteran masa kini dihadapkan pada kontradiksi antara etika, moral, hukum, dan kemampuan serta teknologi kesehatan yang sedemikian maju.

Indonesia memang belum mengatur secara spesifik dan tegas mengenai masalah euthanasia dan hal ini masih menjadi perdebatan pada beberapa kalangan yang menyetujui tentang euthanasia dan pihak yang tidak setuju tentang hal tersebut. Pihak yang menyetujui tindakan euthanasia beralasan bahwa setiap manusia memiliki hak untuk hidup dan hak untuk mengakhiri hidupnya dengan segera dan hal ini dilakukan dengan alasan yang cukup mendukung, yaitu alasan kemanusiaan. Dengan keadaan pasien yang tidak lagi memungkinkan untuk sembuh atau bahkan hidup, maka ia dapat melakukan permohonan untuk segera diakhiri hidupnya. Sementara sebagian pihak yang tidak memperbolehkan euthanasia beralasan bahwa setiap manusia tidak memiliki hak untuk mengakhiri hidupnya karena masalah hidup dan mati adalah kekuasaan mutlak Tuhan yang tidak bisa diganggu gugat oleh manusia. Secara umum, argumen pihak anti euthanasia adalah kita harus mendukung seseorang untuk hidup, bukan menciptakan struktur yang mengizinkan mereka untuk mati.

Perdebatan ini tidak akan pernah berakhir karena sudut pandang yang digunakan sangat bertolak belakang dan lagi-lagi alasan perdebatan tersebut adalah masalah legalitas dari tindakan euthanasia sendiri sampai pada saat ini masih mengalami proses perdebatan panjang, dimana perdebatan tersebut, Euthanasia atau suntik mati olehdokter terhadap seorang pasien yang sudah tidak memiliki kemampuan mengobati penyakitnya saat ini masih merupakan perbuatan pidana berupa menghilangkan nyawa orang lain. Untuk menempuh euthanasia, selain masih ada persoalan hukum yang melarang hal itu, juga masih ada persoalan etika dan moral. Masih berlakukah sumpah etik dokter, yang berasal dari sumpah Bapak Ilmu Kedokteran Yunani, Hippokrates (400 SM), tak akan kulakukan, walaupun atas permintaan, untuk memberikan racun yang mematikan, ataupun sekedar saran untuk menggunakannya, Pro dan kontra mengenai boleh tidaknya euthanasiadilakukan haruslah dilihat dalam keadaan senyatanya, tetapi akan lebih baik lagi bila sebelum dilakukan didahului pengkajian secara komprehensif, syarat ketat, dan regulasi peraturan.

Terdapat juga pendapat dari Dr. R. Soeprono (dalam Prakoso, 1984:54) yang membagi euthanasia empat bentuk yaitu:

a. Euthanasia sukarela (Voluntary euthanasia). Pasien meminta, memberi ijin atau persetujuan untuk menghentikan atau meniadakan perawatan yang memperpanjang hidup.

b. Euthanasia terpaksa (Invulunturv
eulfzunusiu) Membiarkan pasien mati tanpa sepengetahuan si pasien sebelumnya dengan cara menghentikan atau meniadakan perawatan yang memperpanjang hidup.

c. Mercy Killing sukarela (Volunturi Mercy Killing) 
Dengan sepengetahuan dan persetujuan pasien diambil tindakan yang menyebabkan kematian.

d. Mercy Killing terpaksa (Involunlari Alercv Killing)

Tindakan sengaja di ambil tanpa sepengetahuan si pasien untuk mempercepat kematian.

\section{NEGARA HUKUM DAN PELINDUNGAN HAK ASASI MANUSIA}

Sebagaimana telah dipahami bersama, bahwa sebuah Negara merupakan sebuah Negara hukum jika bercirikan 4 (empat) hal, Pertama, pemerintah semata-mata bertindak atas dasar hukum yang berlaku; Kedua, masyarakat dapat naik banding di pengadilan terhadap keputusan pemerintah dan pemerintah taat pada keputusan hakim; Ketiga, hukum sendiri adalah adil dan menjamin hak asasi manusia; Keempat, kekuasaan kehakiman independen dari kemauan pemerintah (Effendi, 1994:94).

Konsep yang berkambang Negara hukum formal, karena adanya kepantingan umum yang harus diselenggarakannya, namun harus sesuai dengan persetujuan perwakilan sehingga menghasilkan undang-undang (wetten staat) atau pemerintah berdasarkan undang-undang (wet-meting bestuur). Perkembangan selanjutnya ialah bahwa tidak perlu berdasar undang-undang, asal berdasarkan hukum (recht-matig bestuur). Konsepsi ini disebut Negara hukum materiil. Selanjutnya pada unsur rech-matig di tambahkan doelmati bestuur, sehingga konsepsinya berkambang menjadi Negara kemakmuran (weivaart ataat, wohlfahrtaat, social service staat) (Wahyono, 1989:17).

Apabila dikaji lebih dalam lagi bahwa Negara hukum harus memiliki unsur-unsur tertentu yang harus dipenuhi sehingga konsekiensi dan eksistensi sebagai sebuah Negara hukum dapat berjalan sebagai cita hukum yang ditetapkan oleh Negara tersebut. Dengan mengacu kepada perkembangan konsepsi Negara hukum maka menurut J. Stahl (dalam Wahyono, 1989:19), harus mengacu kepada unsur-unsur: (a) melindungi hak asasi manusia, (b) untuk dapat melindungi dengan baik harus dengan sistem trias politica atau variasivariasinya, (c) pemerintahannya dimulai dengan wetmatig, recmatig dan doelmatig-bestur, (d) apabila didalam melindungi hak asasi sekalipun sudah wetmatig, recmatig dan doelmatig-bestur teapi masih melanggar hak asasi perseorangan, maka harus diadili.
Secara harfiah hak asasi manusia adalah hak yang melekat pada diri manusia, bersifat universal dan langgeng dan oleh karena itu harus dilindungi, dihormati, dipertahankan dan tidak boleh diabaikan, dikurangi dan dirampas oleh siapapun. Jadi hak asasi manusia dalah hak yang dimiliki manusia semata-mata karena ia sebagai manusia. Ramdhon Naning menyatakan: "hak asasi manusia ialah hak yang dimiliki seseorang karena orang itu adalah manusia" (Naning, 1983:7). Sedangkan Suhardi (dalam Fajar, 2005:44) menyatakan:

"Hak asasi manusia adalah hak yang melekat pada pribadi manusia sejak manusia dilahirkan untuk mempertahankan martabat dan nilai kemanusiaannya (human worth and diginity) yang tidak mengenal pengolongan ras, bangsa agama, derajat serta keduduan. Hak asasi manusia inherent dengan kodrat manusia, merupakan keluasaan atau kebebasan manusia yang di terima dan di hargai sebagai nilai-nilai sosial yang masing-masing dan bersama-sama mutlak dibutuhkan untuk perwujudan realitas manusia, yaitu seasli-aslinya seperti yang digariskan oleh Tuhan".

\section{JENIS EUTHANASIA}

Dr. H. Akbar mengemukakan, Euthanasia aktif dan euthanasia pasif, penderita gawat dan darurat dirawat di rumah sakit atau dibagian rumah sakit gawat darurat dengan peralatan yang majemuk untuk menolong jantung, pernapasan dan cairan tubuh, sehingga alat-alat tubuh itu dapat berfungsi dengan baik (Soekanto, 1990:45).

Euthanasia bisa ditinjau dari berbagai sudut, seperti cara pelaksanaanya, dari mana datang permintaan, sadar tidaknya pasien, dan lain-lain. Secara garis besar, euthanasia dikelompokan dalam dua kelompok, yaitu euthanasia aktif dan euthanasia pasif dan berdasarkan kondisi pasien, euthanasia dibagi menjadi euthanasia volunteer dan euthanasia involunteer. Di bawah ini dikemukakan beberapa jenis euthanasia, yaitu euthanasia aktif, euthanasia pasif, euthanasia volunteer, dan eathanasia involunteer.

Euthanasia aktif adalah perbuatan yang dilakukan secara aktif oleh dokter untuk mengakhiri hidup pasien yang dilakukan secara medis. 
Biasanya dilakukan dengan penggunaan obat-obatan yang bekerja cepat dan mematikan dan Euthanasia aktif dilakukan dengan menghentikan segala alat-alat pembantu dalam perawatan, sehingga jantung dan pernafasan tidak dapat bekerja dan akan berhenti berfungsi, atau memberikan obat penenang dengan dosis yang melebihi, yang juga akan menghentikan fungsi jantung. Euthanasia aktif terbagi menjadi dua golongan, yaitu:

a. Euthanasia aktif langsung, yaitu cara pengakhiran kehidupan melalui tindakan medis yang diperhitungkan akan langsung mengakhiri hidup pasien. Misalnya dengan memberi tablet sianida atau suntikan zat yang segera mematikan.

b. Euthanasia aktif tidak langsung, yaitu cara yang menunjukkan bahwa tindakan medis yang dilakukan tidak akan langsung mengakhiri hidup pasien, tetapi diketahui bahwa risiko tindakan tersebut dapat mengakhiri hidup pasien. Misalnya, mencabut oksigen atau alat bantu kehidupan lainnya.

Euthanasia pasif adalah perbuatan menghentikan atau mencabut segala tindakan atau pengobatan yang perlu untuk mempertahankan hidup manusia,Euthanasiapasif di lakukan bila penderita gawat darurat tidak diberi obat sama sekali, sehingga pasien diperkirakan akan meninggal setelah tindakan pertolongan dihentikan.

Euthanasia volunter (Euthanasia secara sukarela) adalah penghentian tindakan pengobatan atau mempercepat kematian atas permintaan sendiri. Adakalanya hal itu tidak harus dibuktikan dengan pernyataan tertulis dari pasien atau bahkan bertentangan dengan pasien.

Euthanasia involunter (Euthanasia secara tidak sukarela) adalah jenis euthanasia yang dilakukan pada pasien dalam keadaan tidak sadar yang tidak mungkin untuk menyampaikan keinginannya. Dalam hal ini dianggap keluarga pasien yang bertanggung jawab atas penghentian bantuan pengobatan. Perbuatan ini sulit dibedakan dengan perbuatan kriminal.

\section{PERTANGgUNG JAWABAN PIDANA PELAKU ATAU KELUARGA SUNTIK MATI (EUTHANASIA)}

Pada masa kini masalah euthanasia manjadi sebuah perdebatan panjang di banyak negara khususnya negara-negara yang menganut kebebasan dalam melaksanakan hukum eutanasia tersebut, di berbagai nagara masih saja tidak bisa menghasilkan suara yang bulat apakan euthanasia boleh atau tidak dilakukan pada seseorang, permasalahan ini sampai masuk kenegara Indonesia, dalam pendangan di Indonesia sendiri eurtanasia masih saja diperdebatkan dengan bermacam arguamen baik dari pihak kubu yang pro maupun dari kubu yang kontra, masing-masing memiliki argument terhadap pembenaran alasan masing-masing.Pada prinsipnya, hak untuk hidup merupakan hak fundamental atau hak asasi dari setiap manusia. Konstitusi kita yakni UUD 1945 melindungi hak untuk hidup ini dalam Pasal 28A UUD 1945 yang menyebutkan bahwa setiap orang berhak untuk hidup serta berhak mempertahankan hidup dan kehidupannya.

Hak pasien untuk mati, yang seringkali dikenal dengan istilah euthanasia, sudah kerap dibicarakan oleh banyak ahli. Namun masalah ini akan terus menjadi bahan perdebatan yang panjang dan melelehkan, terutama jika terjadi kasus-kasus menarik. Didalam permasalahanEutanasaia terdapat banyak sekali aspek-aspek yang melatarbelakangi permasalahan tersebut karena akan dikaji dan diliat dari banyak sekali sudut pandang seperti dari sudut pandang agama, moral, medis, sertahokum sendiri yang belum menemukan kata sepakat dalam menghadapi keinginan pasien untuk mati guna menghentikan penderitaannya. Situasi ini menimbulkan dilema bagi para dokter, apakah ia mempunyai hak hukum untuk mengakhiri hidup seorang pasien atas permintaan pasien itu sendiri atau keluarganya, dengan dalih mengakhiri penderitaan yang berkepanjangan, tanpa dokter itu sendiri menghadapi konsekuensi hukum. Sudah barang tentu dalam hal ini dokter tersebut menghadapi konflik dalam batinnya.

Klasifikasi Euthanasia ada beberapa macam diantaranaya adalah sebagai berikut: (a) voluntary euthanasia, jika yang membuat keputusan adalah orang yang sakit, (b) involuntary euthanasia, jika yang membuat keputusan adalah orang lain seperti pihak keluarga atau dokter karena pasien mengalami koma medis.

Menurut Veronica Komalawati, ahli hukum kedokteran dan staf pengajar pada Fakultas Hukum UNPAD dalam artikel harian Pikiran Rakyat mengatakan bahwa euthanasia dapat dibedakan menjadi euthanasia aktif, euthanasia pasif. Euthanasia aktif adalah tindakan secara sengaja yang dilakukan dokter atau tenaga 
kesehatan lain untuk memperpendek atau mengakhiri hidup si pasien. Misalnya, memberi tablet sianida atau menyuntikkan zat-zat berbahaya ke tubuh pasien.

Euthanasia pasif. Dokter atau tenaga kesehatan lain secara sengaja tidak (lagi) memberikan bantuan medis yang dapat memperpanjang hidup pasien. Misalnya tidak memberikan bantuan oksigen bagi pasien yang mengalami kesulitan dalam pernapasan atau tidak memberikan antibiotika kepada penderita pneumonia berat, dan melakukan kasus malpraktik. Disebabkan ketidaktahuan pasien dan keluarga pasien, secara tidak langsung medis melakukan euthanasia dengan mencabut peralatan yang membantunya untuk bertahan hidup. Autoeuthanasia. Seorang pasien menolak secara tegas dengan sadar untuk menerima perawatan medis dan ia mengetahui bahwa itu akan memperpendek atau mengakhiri hidupnya.

Sampai sejauh ini Indonesia memang belum mengatur secara spesifik dan jelas mengenai mengenai euthanasia (Mercy Killing). Euthanasia atau menghilangkan nyawa orang atas permintaan sendiri sama dengan perbuatan pidana menghilangkan nyawa seseorang. Konsep Euthanasia sekarang ini masih menjadi perdebatan para pakar hukum, ada yang setuju tentang euthanasia dan ada pula pihak yang tidak setuju tentang euthanasia. Pihak yang menyetujuieuthanasia mengemukakan pendapat berdasarkan bahwa setiap manusia mempunyai hak untuk hidup dan hak untuk mengakhiri hidupnya dengan segera dengan alasan kemanusiaan. Dengan keadaan dirinya yang tidak lagi memungkinkan untuk sembuh atau bahkan hidup, maka ia dapat melakukan permohonan untuk segera diakhiri hidupnya.

Sementara sebagian pihak yang tidak membolehkan euthanasia beralasan bahwa setiap manusia tidak memiliki hak untuk mengakhiri hidupnya, karena masalah hidup dan mati adalah kekuasaan mutlak Tuhan yang tidak bisa diganggu gugat oleh manusia. Dua pandangan tersebut semakin membuat panjang perdebatan tentang boleh tidaknya dilakukan euthanasia dalam system hukum di Indeonesia. Di Indonesia suntik mati ataueuthanasia dengan menyuntik mati akandisamakan dengan tindakan pidana pembunuhan seperti apa yang sudah ada dalam Kitab Undang-Undang Hukum Pidana (KUHP). Di Indonesia masalah euthanasia masih belum mandapatkan tempat yang diakui secara yuridis dan mungkinkah dalam perkembangan Hukum Positif Indonesia, euthanasia akan mendapatkan tempat yang diakui secara yuridis.

Menyinggung masalah kematian, menurut cara terjadinya, maka ilmu pengetahuan membedakannya ke dalam tiga jenis kematian, yaitu: (a) orthothanasia, yaitu kematian yang terjadi karena suatu proses alamiah, (b) dysthanasia, yaitu suatu kematian yang terjadi secara tidak wajar, (c) buthanasia, yaitu suatu kematian yang terjadi dengan pertolongan atau tidak dengan pertolongan dokter (Sinar Harapan, 1977:8).

Untuk euthanasia aktif maupun pasif tanpa permintaan, ada beberapa pasal yang berkaitan atau dapat menjelaskandasar hukum dilakaukannya euthanasia bagi orang atau keluarga yang mengajukan untuk dilakukan euthanasia:

1. Pasal 340 KUHP

Barang siapa yang dengan sengaja dan direncanakan lebih dahulu menghilangkan jiwa orang lain, dihukum, karena pembunuhan direncanakan (moord), dengan hukuman mati atau pejara selama-lamanya seumur hidup atau penjara sementara selama-lamanya dua puluh tahun.

2. Pasal 359

Barang siapa karena salahnya menyebabkan matinya orang, dihukum penjara selamalamanya lima tahun atau kurungan selamalamanya satu tahun.

3. Pasal 345

Barang siapa dengan sengaja menghasut orang lain untuk membunuh diri, menolongnya dalam perbuatan itu, atau memberikan daya upaya itu jadi bunuh diri, dihukum penjara selama-lamanya empat tahun penjara.

Berdasarkan penjelasan pandangan hukum terhadap tindakan euthanasia dalam skenario ini, maka dokter dan keluarga yang memberikan izin dalam pelaksanaan tindakan tersebut dapat dijeratkan dengan pasal 345 KUHP yang ber bunyi barang siapa dengan sengaja mendorong orang lain untuk bunuh diri, atau memberikan sarana kepadanya untuk itu, diancam dengan pidana penjara dengan acaman penjara selamalamanya empat tahun penjara (Moeljatno, 1999:127).Dengan tidak adanya regulasi yang jelas di Indonesia maka dapat dipastikan bahwa suntuk mati (euthanasia) masih belum mempunyai dasar hokum yang jelas untuk melakukan tindakan suntik mati atau euthanasia tersebut. 
Patut menjadi catatan, bahwa secara yuridis formal dalam hukumpidana positif di Indonesia hanya dikenal 2 bentuk euthanasia, yaitu euthanasia yang dilakukan atas permintaan pasien atau korban itu sendiri dan euthanasia yang dilakukan dengan sengaja melakukan pembiaran terhadap pasien/ korban sebagaimana secara eksplisit diatur dalam Pasal 344 dan 304 KUHP. Pasal 344 KUHP secara tegas menyatakan : (Moeljatno, 2005 : 116)

"Barang siapa merampas nyawa orang lain atas permintaan orang itu sendiri yang jelas dinyatakan dengan kesungguhan hati diancam dengan pidana penjara paling lama dua belas tahun"

Sementara dalam pasal 304 KUHP dinyatakan:

"Barang siapa dengan sengaja menempatkan atau membiarkan seorang dalam keadaan sengsara,padahal menurut hukum yang berlaku baginya atau karena persetujuan dia wajib memberi kehidupan,perawatan atau pemeliharaan kepada orang itu,diancam dengan pidana penjara paling lama dua tahun delapan bulan atau pidana denda paling banyak empat ribu lima ratus rupiah"

Bertolak dari ketentuan Pasal 344 dan 304 KUHP tersebut tersimpul, bahwa pembunuhan dengan sengaja membiarkan sengsara dan atas permintaan korban sekalipun tetap diancam pidana bagi pelakunya. Dengan demikian, dalam konteks hukum positif di Indonesia euthanasia tetap dianggap sebagai perbuatan yang dilarang. Dengan demikian dalam konteks hukum positif di Indonesia, tidak dimungkinkan dilakukan "pengakhiran hidup seseorang" sekalipun atas permintaan orang itu sendiri. Perbuatan tersebut tetap dikualifikasi sebagai tindak pidana, yaitu sebagai perbuatan yang diancam dengan pidana bagi siapa yang melanggar larangan tersebut.

\section{SUNTIK MATI (EUTANASIA) DAPAT DIKATEGORIKAN SEBAGAI PELANG- GARAN HAK ASASI MANUSIA (HAM)}

Perbedaan pendapat apakah suntik mati (euthanasia) melanggar hak asasi manusia ataukan tidak melanggar, ini masih menjadi perdebartan panjang, saat ini euthanase mengalami pergeseran makna. seiring dengan bergesernya makna tersebut melahirkan penafsiran-penafsiran baru tentang euthanasia. Maka dari itu, sekarang pengertian euthanasia lebih mengarah kepada tindakan mengakhiri hidup yang dilakukan para medis untuk mengurangi penderitaan pasienya. Akibat beragamnya penafsiran tentang euthanasia inilah sehinggga sekarang euthanasia menjadi bahan perdebatan. Antara euthanasia melanggar hak asasi manusia atau tidak melanggar hak asasi manusia.

Hak hidup adalah hak untuk menjalani kehidupan tanpa gangguanyang mengakibatkan hilangnya nyawa seseorang. Hak ini merupakan hak asasiyang paling esensial dari keseluruhan hak yang dimiliki oleh manusia. Termasukdalam kategori ini adalah hak untuk menjalankan kehidupan yang layak di manapundan kapanpun (Maududi, 1995:21).

Pendapat dari pendukung euthanasia beranggapan bahwa memaksa seseorang untuk melanjutkan kehidupannya yang penuh dengan penderitaan dan siksaan penyakit, baik fisik maupun materi adalah merupakan tindakan irasional dan tidak menghargai hak asasi manusia, di mana seseorang memiliki hak terhadap dirinya sendiri untuk menentukan sikap dan keputusan atas kelanjutan hidupnya. Hal ini perlu dihormati dan dihargai (As-Syaukani, 1998:179).

Konstitusi dan hukum Indonesia memberikan jaminan penuh terhadap hak hidup manusia yang tertuang dalam Undang-undang Dasar NRI 1945 dan Undang-Undang No. 39 Tahun 1999 tentang Hak Asasi Manusia. Dalam kedua sumber hukum ini, hak hidup dinyatakan sebagai sebuah hak yang melekat pada setiap warga negara Indonesia. Sanksi hukum akan berlaku jika hak tersebut dilanggar, sesuai dengan kreteria tindakan melanggar hukum yang ditetapkan dalam sumber hukum materil tersebut.

Pada penjelasan pasal 4 Undang-undang No. 39 Tahun 1999 tentang Hak Asasi Manusia, dinyatakan bahwa setiap orang memiliki hak hidup, hak untuk tidak disiksa, hak kebebasan pribadi, pikiran dan hati nurani, hak beragama,hak untuk tidak diperbudak, hak untuk diakui sebagai pribadi dan persamaan di hadapan hukum, dan hak untuk tidak dianaut atas dasar hukum yang berlaku surut adalah hak asasi manusia yang tidak bisa dikurangi dalam keadaan apapun dan oleh siapapun. Hak atas kehidupan ini bahkan melekat pada bayi yang belum lahir, dengan adanya larangan abortus. 
Jika kita menilai euthanasia dari aspek hak asasi manusia. Tindakan euthanase adalah perbuatan melanggar hak asasi manusia. Ada beberapa alasan sehingga tindakan euthanasia melanggar hak dasar kehidupan manusia, melanggar deklarasi yang dikeluarkan PBB, pasal 28A Undang-Undang Dasar Negara Republik Indonesia Tahun 1945, Kitab Undang-Undang Hukum Pidanadan yang paling penting adalah melangkahi wewenang dari kewanangan TuhanYang Maha Kuasa.

Sebagai salah satu negara anggota PBB, Indonesia ikut meratifikasi Piagam Hak Asasi Manusia sesuai dengan Undang-Undang Dasar 1945, selanjutnya Majelis Permusyawaratan Rakyat menetapkan sebuah keputusan tentang hak asasi manusia yang diputuskan dalam TAP MPRNO. XVII/MPR/1998 tentang Pandangan dan Sikap Bangsa Indonesia terhadap HAM dan Piagam HAM Nasional, dan Undang-Undang No. 39 tahun 1999Tentang Hak Asasi Manusia, dengan dua sumber ini maka kedudukan HAMdalam konstitusi Indonesia semakin kuat, sehingga kehendak untuk menegakkanHAM di Indonesia mendapat legalitas formal. Setelah pemberlakuan HAM ini, hak hidup memiliki jaminan penuh dan dilindungi oleh konstitusi (Tim ICCE UIN Jakarta, 2003:225).

\section{SIMPULAN}

Bahwasannya suntik mati (euthanasia) sampai saaat ini masih belum ada regulasi atau peraturan yang legal diterapkan dan berlaku di

\section{DAFTAR RUJUKAN}

Achadiat. C.M. 2002. Euthanasia yang semakin Kontroversial. Medika/arsip/01 2002/top1.htm.

Anonimous. 2007. Undang-undang Hak Asasi Manusia. Penerbit. Visi Media. Bertens. 2005. Etika. Penerbit. PT. Gramedia Pustaka Utama. Jakarta.

Budiman. A. 1993. Posisi Tawar Menawar Rakyat Dalam Hak Asasi Manusia. Jawa Pos. Selasa Pahing. 2 Februari

Effendi. H.A. M. 1994. Hak Asasi Manusia

Dalam Dimensi Hukum Nasional Dan

Hukum Internasional. Ghalia Indonesia. Jakarta.

Gunawan. 1991. Memahami Etika Kedokteran. Yogyakarta. Penerbit Kanisius.
Indonesia, Pertanggung jawaban pidana pelaku atau keluarga suntik mati (euthanasia), saaat ini euthanasia lebih sering di perbincangkan dan di samakan dengan sebuah tindakan dari dokter atau tenaga kesehatan yang melakukan tindakan atau berpuatan menyuntik mati seorang pasien atas permintaan pasien sendiri maupun dari permintaan keluarga korban, ada pendapat yang beragam tentang pro serta kontara tentang suntik mati atau (euthanasia).

Dalam aturan secara yuridis formal dalam hukum pidana positif di Indonesia hanya dikenal 2 bentuk euthanasia, yaitueuthanasia yang dilakukan atas permintaan pasien atau korban itu sendiri dan euthanasia yang dilakukan dengan sengaja melakukan pembiaran terhadap pasien atau korban sebagaimana secara eksplisit diatur dalam Pasal 344 dan 304 KUHP yang secara jelas menjelaskan tentang pasal mengenai permasalahan yang identik dengan euthanasia.

Konstitusi dan hukum Indonesia memberikan jaminan penuh terhadap hak hidup manusia yang tertuang dalam Undang-undang Dasar 1945 dan Undang-Undang No. 39 Tahun 1999 tentang Hak Asasi Manusia. Dalam kedua sumber hukum ini, hak hidup dinyatakan sebagai sebuah hak yang melekat pada setiap warga negara Indonesia. Sanksi hukum akan berlaku jika hak tersebut dilanggar, sesuai dengan kreteria tindakan melanggar hukum yang ditetapkan dalam sumber hukum materil tersebut.

Hadiwardoyo. P. 1989. Etika Medis. Jakarta: Pustaka filsafat.

Hilman, 2004. Euthanasia. Sebuah pemikiran. 1004/12/0801.htm Karyadi. P.Y.2001. Euthanasia dalam Perspektif Hak Asasi Manusia,Penerbit. Media Pressindo.

Mahasin. A. 1979. Hak-hak Asasi Manusia: Dari Konstitusional ke Persoalan Struktural. PRISMA No. 12 Desember.

Notohamidjodjo. D. 1970. Demi Keadilan Dan Kemanusiaan. BPK. Gunung Mulia. Jakarta.

Oemar. S. A. 1991. Etika Profesional Dan Hukum Pertanggungjawaban Pidana Dokter. Jakarta. Penerbit Erlangga. 
Prakoso. D. dan D. A. Nirwanto. 1984. Euthanasia Hak Asasi Manusia dan Hukum Pidana. Ghalia Indonesia.

Prodjodikoro. W. 1977. Hukum Acara Pidana

Di Indonesia. Sumur. Bandung. Rahardjo. S. 1989. Asas-Asas Hukum Nasional. BPHN. Jakarta.
Samil. R. S. 1994. Etika Kedokteran Indonesia (Kumpulan Naskah). Jakarta: Fakultas Kedokteran Universitas Indonesia.

Soekanto. 1989. Aspek Hukum Kesehatan (Suatu Kumpulan Catatan). Penerbit. IND-Hill-Co. Jakarta. 